\title{
Life history of Neoseiulus californicus (McGregor, 1954) (Acari: Phytoseiidae) fed with castor bean (Ricinus communis L.) pollen in laboratory conditions
}

\author{
Marafeli, PP. ${ }^{a, b *}$, Reis, PR. ${ }^{a}$, Silveira, EC. d $a^{a, b}$, Souza-Pimentel, GC. ${ }^{a, b}$ and Toledo, MA. de $e^{a, b}$

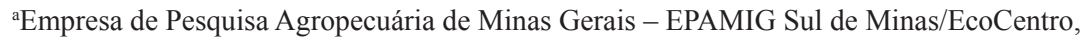 \\ CP 176, CEP 37200-000, Lavras, MG, Brazil

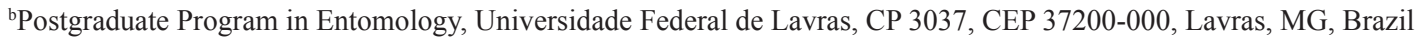 \\ *e-mail: paduamara@yahoo.com.br
}

Received: July 16, 2012 - Accepted: May 16, 2013 - Distributed: August 31, 2014

\begin{abstract}
The predatory mite, Neoseiulus californicus (McGregor, 1954) (Acari: Phytoseiidae) is one of the principal natural enemies of tetranychid mites in several countries, promoting efficient control of those mites in several food and ornamental crops. Pest attacks such as that of the spider mite, Tetranychus urticae Koch, 1836 (Acari: Tetranychidae), is one of the problems faced by farmers, especially in the greenhouse, due to the difficulty of its control with the use of chemicals because of the development of fast resistance making it hard to control it. The objective of this work was to study the life history of the predatory mite $N$. californicus as a contribution to its mass laboratory rearing, having castor bean plant [Ricinus communis L. (Euphorbiaceae)] pollen as food, for its subsequent use as a natural enemy of T. urticae on a cultivation of greenhouse rosebushes. The studies were carried out in the laboratory, at $25 \pm 2^{\circ} \mathrm{C}$ of temperature, $70 \pm 10 \% \mathrm{RH}$ and a 14 hour photophase. The biological aspects and the fertility life table were appraised. Longevity of 32.9 days was verified for adult females and 40.4 days for males. The intrinsic rate of increase $\left(\mathrm{r}_{\mathrm{m}}\right)$ was 0.2 and the mean generation time (T) was 17.2 days. The population doubled every 4.1 days. The results obtained were similar to those in which the predatory mite $N$. californicus fed on T. urticae.
\end{abstract}

Keywords: agricultural acarology, two spotted spider mite, Tetranychus urticae, fertility life table, biology.

\section{História de vida de Neoseiulus californicus (McGregor, 1954) (Acari: Phytoseiidae), alimentado com pólen de mamoneira (Ricinus communis L.) em condição de laboratório}

\section{Resumo}

O ácaro predador, Neoseiulus californicus (McGregor, 1954) (Acari: Phytoseiidae) é um dos principais inimigos naturais de ácaros tetraniquídeos em vários países, promovendo um eficiente controle em várias culturas alimentícias e ornamentais. O ataque de pragas como o ácaro-rajado, Tetranychus urticae Koch, 1836 (Acari: Tetranychidae), é um dos problemas enfrentados pelos produtores, principalmente em casa de vegetação, pela dificuldade de seu controle com o uso de agroquímicos devido ao rápido desenvolvimento de resistência o que dificulta seu controle. Foi objetivo deste trabalho estudar a história de vida do ácaro predador $N$. californicus como contribuição à sua criação massal em laboratório tendo como alimento pólen de mamoneira [Ricinus communis L. (Euphorbiaceae)] para posterior uso como inimigo natural de T. urticae em cultivo de roseiras (Rosa spp.) em casa de vegetação. Os estudos foram conduzidos em laboratório à temperatura de $25 \pm 2^{\circ} \mathrm{C}, 70 \pm 10 \%$ de UR e 14 horas de fotofase. Foram avaliados os aspectos biológicos e confeccionada a tabela de vida de fertilidade. Foi constatada uma longevidade de 32,9 dias para fêmeas adultas e 40,4 dias para machos. A estimativa da capacidade inata de crescimento da população $\left(\mathrm{r}_{\mathrm{m}}\right)$ foi 0,2 dias e a duração média de geração (T) foi 17,2 dias. A população dobrou a cada 4,1 dias. Os resultados obtidos foram semelhantes àqueles nos quais o predador $N$. californicus foi alimentado com T. urticae.

Palavras-chave: acarologia agrícola, ácaro-rajado, Tetranychus urticae, tabela de vida de fertilidade, biologia. 


\section{Introduction}

The predatory mites of the family Phytoseiidae constitute one of the principal natural enemies of phytophagous mites on the rosebush (Rosa spp.) culture, as well as in other ornamental and horticultural cultures produced in greenhouses, where they find favourable conditions which enable their possible use in biological control. Among the principal species of predatory mites used in the greenhouse there is the Neoseiulus californicus (McGregor, 1954) (Phytoseiidae) (REIS et al., 2005).

Biological control with the use of predatory mites is widely employed in North and South America, Asia and Europe. In Brazil, the species N. californicus and Phytoseiulus macropilis (Banks, 1904) are the most studied, therefore, besides being effective in the control of the spider mite in various cultures, they are already commercially produced, which allows their mass liberation in crops (SATO et al., 2002a; POLETTI et al., 2006).

The predation capacity of $N$. californicus is approximately fifteen to twenty spider mite eggs per day, feeding on all of the biological stages of the prey. As it is a generalist, it can also feed on other sources, such as pollen, other mites, thrips and aphids, thus surviving for days without the presence of the prey in the field (MORAES and FLECHTMANN, 2008).

Works conducted in Brazil on the use of predatory mites, especially $N$. californicus and P. macropilis, have been revealing high potential of those species in the control of Tetranychus urticae Koch, 1836 (Acari: Tetranychidae), mainly in protected cultivations systems (SATO et al., 2002b, 2006; POLETTI et al., 2006).

The two spotted spider mite, T. urticae, cosmopolitan and polyphagous, is considered one of the most important pest mite species. It is described as attacking more than 1,100 species of plants in 140 families of economic value (GRBIĆ et al., 2011; UNIVERSITY OF UTAH, 2011).

The two spotted spider mite is a pest in fruits, such as the strawberry plant (Fragraria spp.), papaya tree (Carica papaya L.), peach tree (Persian prunus L.) etc., and ornamental plants, such as the chrysanthemum (Chrysanthemum spp.), rose (Rosa spp.) etc., besides other cultures (CHAPMAN and MARTIN, 2005; FADINI et al., 2006; MORAES and FLECHTMANN, 2008).

In the greenhouse, the maintenance of relatively stable environmental conditions for the development of plants usually favours the fast development of the pest, increasing the population before the producer notices. For dealing with a closed and artificial environment, it hinders the appearance of natural enemies and favours the fast evolution of pest mite resistance to the pesticides used (ZHANG, 2003).

The permanent study of management of pests that occur in protected cultivation systems is necessary in order to ensure efficient, economic, and ecologically sustainable control.

A common method to control the spider mite is the application of synthetic acaricides (SATO et al., 2007).
However, in many situations, the synthetic acaricides have selected resistant populations, generating the need for additional spraying and/or dosage increases (SATO et al., 2007, 2009).

Keeping in mind the need for efficient, less troublesome control, that is health friendly to the rose farmers, as well as contributing to environmental preservation, the study of the management of this culture regarding pest incidence, mainly the incidence of the spider mite, T. urticae, and its biological control with predatory mites, is necessary considering successful experiences that have been occurring throughout the world in several greenhouse cultures (OPIT et al., 2004; FERRERO et al., 2011; ALATAWI, et al., 2011).

In a greenhouse, the development cycle of the mite T. urticae is highly variable in function of the temperature, but under hot and dry weather conditions, it can complete its cycle in only seven days. High temperature and low relative humidity conditions favour the development of that mite. The egg to adult biological cycle has an average duration of ten days, and it is easily adaptable and possesses a high ability to acquire resistance to phytosanitary products (REIS et al., 2005).

This work was conducted with the aim of studying the biological parameters of the predatory mite $N$. californicus fed with pollen of castor bean plant (Ricinus communis L., Euphorbiaceae) as a contribution to its mass rearing and use in the biological control of T. urticae in the greenhouse.

\section{Material and Methods}

The experiments were conducted in the Acarology Laboratory of the Centro de Pesquisa em Manejo Ecológico de Pragas e Doenças de Plantas - EcoCentro, ofthe Empresa de Pesquisa Agropecuária de Minas Gerais - EPAMIG Sul de Minas, atthe Universidade Federal de Lavras - UFLA campus, in Lavras, $\mathrm{MG}$, at $25 \pm 2{ }^{\circ} \mathrm{C}$ of temperature, $70 \pm 10 \% \mathrm{RH}$ and a 14 hour photophase.

\subsection{Maintenance rearing of Neoseiulus californicus and Tetranychus urticae}

The rearing of $N$. californicus was initiated with mites from a pre-existent rearing on Jack-bean leaves, Canavalia ensiformes (L.), free from pesticide application and infested with T. urticae, located in the Acarology Laboratory do Instituto Federal de Educação, Ciência e Tecnologia do Sul de Minas Gerais, campus de Inconfidentes, MG. The mites were taken to the Laboratory of EcoCentro in Lavras and were maintained in $3 \mathrm{~cm}$ diameter arenas of flexible PVC plastic, floating in distilled water in $15 \mathrm{~cm}$ diameter Petri dishes, according to the methodology of Reis and Alves (1997). The predators were fed with castor bean pollen.

\subsection{Biological aspects of Neoseiulus californicus}

All the biological characteristics of $N$. californicus were obtained with castor bean plant pollen as food.

The studies were conducted in $3 \mathrm{~cm}$ diameter arenas, made with black flexible plastic PVC sheets, floating 
in water in $15 \mathrm{~cm}$ diameter Petri dishes $2 \mathrm{~cm}$ deep, as mentioned previously.

For the observation of the embryonic stage, eggs of the predator with less than 12 hours of age were individualised and maintained on disks, totalling 5 five arenas per $15 \mathrm{~cm}$ diameter Petri dish, in a total of 20 dishes, which resulted in the study of 100 eggs of the predator. The eggs were observed daily at 8:00 a.m. and 4:00 p.m. to determine the moment of larval eclosion.

After the eclosion of the larvae, the duration (in days) was observed of each developmental stage (larva, protonymph, deutonymph) and the egg-adult stage duration was calculated. In the post-embryonic development, observations of the immature forms were also conducted twice per day, at 8:00 a.m. and 4:00 p.m.. A hundred specimens were used for evaluation of the predatory immature stage. In the adult phase only one observation per day was made, at 8:00 a.m., in couples formed with the females still in the deutonymph stage. The males that died were substituted by others from the laboratory rearing.

\subsection{Fertility life table of Neoseiulus californicus}

Starting from the formation of the couples, with surviving females of the post-embryonic development study, the pre-oviposition periods, oviposition, post-oviposition and the longevity of the female and male were observed, using the methodology described by Reis et al. (2007) in the life history study of Amblyseius herbicolus (Chant, 1959) (Phytoseiidae).

To construct the fertility life table, each couple was confined in black flexible plastic PVC disk arenas of $3 \mathrm{~cm}$ in diameter, floating on distilled water, totalling 5 arenas per $15 \mathrm{~cm}$ diameter Petri dish, for a total of 20 dishes or 100 couples.

Each predator couple was evaluated every 24 hours, with the supply of castor bean pollen as food and the removal of the eggs.

For the calculations, the methodology of Andrewartha and Birch (1954) ${ }^{1}$ apud Silveira Neto et al. (1976) was used. With the values obtained of age intervals (x), specific fertility $(\mathrm{Mx})$ and survival probability (Lx) the following were calculated: the net reproduction rate $\left(\mathrm{R}_{\mathrm{o}}\right)$, the mean generation time $(T)$, the intrinsic rate of increase $\left(r_{m}\right)$, the finite rate of increase $(\lambda)$ and the time required for the population to double in the number (TD), which, according to Tanigoshi et al. (1975) is equal to $\ln 2 / \mathrm{r}_{\mathrm{m}}$.

\section{Results and Discussion}

The results obtained of the biological aspects and fertility life table having castor bean pollen as food will be presented and discussed.

1 ANDREWARTHA, HG. and BIRCH, LC. 1954. The innate capacity for increase in numbers, In: __. (Ed.). The distribution and abundance of animals. Chicago: University of Chicago. p. 31-54.

\subsection{Biological aspects of Neoseiulus californicus}

The average duration of the egg stage was 2.16 and 2.06 days for females and males, respectively. The immature post-embryonic stages presented durations for females and males respectively, of 0.97 and 0.98 day for larva, 0.94 and 0.96 day for protonymph, 1.58 and 1.68 day for deutonymph. The egg to adult development was 5.61 days for females and 5.66 days for males (Table 1).

Gotoh et al. (2004) studied the effect of the temperature on the life history of $N$. californicus fed only with $T$. urticae eggs, and they relate that at $25^{\circ} \mathrm{C}$, the same temperature studied in the present work, the average duration, in days, of the egg phase for females and males, respectively, was 1.7 and 1.9, larva 0.6 and 0.5 , protonymph 1.1 and 0.9 , and deutonymph 1.1 and 1.1, slightly shorter durations a than those found in the present work, probably due to the food source used.

Vasconcelos (2006), at the same temperature, observed a developmental time, in days, of 1.8 and 0.6 for eggs and larvae of that predator when fed with T. urticae and, Canlas et al. (2006) verified 1.4 and 0.8 for eggs and larvae of male predators and 1.6 and 0.8 for eggs and larvae of females, results very close to those obtained in the present work with castor bean pollen. For the deutonymph and protonymph stages the durations were shorter or close to those obtained by Vasconcelos (2006) and Canlas et al. (2006).

The pre-oviposition period observed was 3.83 days, oviposition 19.16 days with total fecundity of $39.22 \mathrm{eggs} /$ female, with an average of 2.03 eggs per day (Table 2$)$. In the results related by Vasconcelos (2006) and Canlas et al. (2006), the pre-oviposition periods were, respectively, 1.7 and 1.68 when $N$. californicus fed on T. urticae, shorter periods than those found in our work when fed on castor bean plant pollen.

The oviposition period presented the same duration as found by Vasconcelos (2006) and Gotoh et al. (2004); the post-oviposition was similar to the results found by Canlas et al. (2006). Rahmani et al. (2009) studied the life history of $N$. californicus having Thrips tabaci (Lindeman, 1888) (Thysanoptera: Thripidae) as prey and they registered 3.54 days regarding the pre-oviposition, 22 days for the oviposition and 3.91 days for the post-oviposition; the oviposition period approximating that found in this work. The fecundity was equal to or higher than in those studies of the cited authors, which suggests, for a mass rearing of $N$. californicus, that the diet with castor bean pollen is a viable alternative, because the developmental time as well as the number of eggs does not vary much when the same mite had T. urticae or T. tabaci as food.

The longevity of the females was 32.94 days, the males 40.36 days, and the sex ratio was 0.36 (Table 1 ). Bellini (2008), studied the development of Neoseiulus barkeri Hughes, 1948 (Acari: Phytoseiidae) offering Phyllocoptruta oleivora (Ashmead, 1879) (Acari: Eriophyidae), Brevipalpus phoenicis (Geijskes, 1939) (Acari: Tenuipalpidae), T. urticae and common cattail pollen, Typha angustifolia 
Table 1. Duration in days of immature stages of Neoseiulus californicus, at $25 \pm 2^{\circ} \mathrm{C}$ of temperature, $70 \pm 10 \% \mathrm{RH}$ and a $14 \mathrm{~h}$ photophase, fed on castor bean plant (Ricinus communis) pollen, compared with three works where the food was Tetranychus urticae.

\begin{tabular}{|c|c|c|c|c|c|c|}
\hline \multirow{2}{*}{$\begin{array}{c}\text { Developmental } \\
\text { stages }\end{array}$} & \multirow[b]{2}{*}{ Sex } & \multirow[b]{2}{*}{ n* } & \multicolumn{4}{|c|}{ Duration in days $\pm \mathrm{SD} * *$} \\
\hline & & & In this paper & $\begin{array}{c}\text { Canlas et al. } \\
(2006)\end{array}$ & $\begin{array}{c}\text { Vasconcelos } \\
(2006) \\
\end{array}$ & $\begin{array}{c}\text { Gotoh et al. } \\
(2004) \\
\end{array}$ \\
\hline \multirow[t]{2}{*}{ Egg } & Female & 36 & $2.16 \pm 0.06$ & $1.4 \pm 0.05$ & $1.8 \pm 0.1$ & $1.7 \pm 0.14$ \\
\hline & Male & 64 & $2.06 \pm 0.03$ & $1.6 \pm 0.04$ & - & $1.9 \pm 0.09$ \\
\hline \multirow[t]{2}{*}{ Larva } & Female & 36 & $0.97 \pm 0.02$ & $0.8 \pm 0.05$ & $0.6 \pm 0.1$ & $0.6 \pm 0.04$ \\
\hline & Male & 64 & $0.98 \pm 0.02$ & $0.8 \pm 0.07$ & - & $0.9 \pm 0.00$ \\
\hline \multirow[t]{2}{*}{ Protonymph } & Female & 36 & $0.94 \pm 0.03$ & $1.0 \pm 0.12$ & $1.0 \pm 0.1$ & $1.1 \pm 0.04$ \\
\hline & Male & 64 & $0.96 \pm 0.03$ & $1.4 \pm 0.07$ & - & $0.9 \pm 0.06$ \\
\hline \multirow[t]{2}{*}{ Deutonymph } & Female & 36 & $1.58 \pm 0.07$ & $0.9 \pm 0.05$ & $1.0 \pm 0.1$ & $1.0 \pm 0.08$ \\
\hline & Male & 64 & $1.68 \pm 0.05$ & $1.2 \pm 0.05$ & - & $1.0 \pm 0.09$ \\
\hline \multirow[t]{2}{*}{ Egg-Adult } & Female & 36 & $5.61 \pm 0.09$ & - & - & $4.3 \pm 0.16$ \\
\hline & Male & 64 & $5.66 \pm 0.07$ & - & - & $4.3 \pm 0.16$ \\
\hline \multirow[t]{2}{*}{ Longevity } & Female & 36 & $32.94 \pm 0.43$ & $29.3 \pm 2.4$ & $29.2 \pm 2.9$ & $33.8 \pm 3.04$ \\
\hline & Male & 64 & $40.36 \pm 0.33$ & - & $23.8 \pm 3.7$ & - \\
\hline Sex ratio & & & 0.36 & 0.52 & 0.78 & 0.69 \\
\hline
\end{tabular}

$* \mathrm{n}=$ Number of mites studied; $* * \mathrm{SD}=$ Standard deviation.

Table 2. Duration in days of the of pre-oviposition, oviposition, post-oviposition periods and number of eggs laid per day by females of Neoseiulus californicus at $25 \pm 2{ }^{\circ} \mathrm{C}, 70 \pm 10 \% \mathrm{RH}$ and a $14 \mathrm{~h}$ photophase, fed on castor bean plant (Ricinus communis) pollen, compared with four works where the food was Tetranychus urticae.

\begin{tabular}{|c|c|c|c|c|c|c|}
\hline \multirow{2}{*}{ Parameters } & \multicolumn{2}{|r|}{ In this paper } & \multirow{2}{*}{$\begin{array}{c}\text { Rahmani et al. } \\
\text { (2009) }\end{array}$} & \multirow{2}{*}{$\begin{array}{c}\text { Canlas et al. } \\
(2006)\end{array}$} & \multirow{2}{*}{$\begin{array}{c}\text { Vasconcelos } \\
(2006)\end{array}$} & \multirow{2}{*}{$\begin{array}{c}\text { Gotoh et al. } \\
(2004)\end{array}$} \\
\hline & $\mathbf{n}^{*}$ & Média \pm SD** & & & & \\
\hline Pre-oviposition & 36 & $3.83 \pm 0.24$ & 3.54 & $1.68 \pm 0.13$ & $1.7 \pm 0.2$ & $1.6 \pm 0.41$ \\
\hline Oviposition & 36 & $19.16 \pm 0.52$ & 22.00 & $17.91 \pm 1.00$ & $19.3 \pm 2.0$ & $19.4 \pm 1.17$ \\
\hline Post-oviposition & 36 & $10.58 \pm 0.35$ & 3.91 & $10.18 \pm 0.88$ & $8.1 \pm 2.6$ & $12.9 \pm 3.17$ \\
\hline No. of eggs/female & 36 & $39.22 \pm 0.63$ & - & $34.73 \pm 2.23$ & - & $41.6 \pm 2.06$ \\
\hline No. of eggs/female/day & 36 & $2.03 \pm 0.05$ & 2.42 & $1.94 \pm 0.24$ & - & $2.2 \pm 0.10$ \\
\hline
\end{tabular}

$* \mathrm{n}=$ Number of females studied; $* * \mathrm{SD}=$ Standard deviation

L. (Typhaceae), as food and did not observe statistical differences when comparing the results obtained with the T. urticae and pollen diets. According to the author, the results with the other foods, than that with $T$. urticae and pollen diets, were not satisfactory for the development of the predator.

\subsection{Fertility life table of Neoseiulus californicus}

The results of the fertility life table showed that the estimate of the innate capacity for predator population growth $\left(\mathrm{r}_{\mathrm{m}}\right)$ was 0.17 females/female/day. This results were close to that observed by Canlas et al., (2006), Vasconcelos, (2006) (Tables 3 and 4).

In studies of the biology of $N$. californicus fed with holm oak pollen, Quercus ilex L. (Fagaceae), Preverieri et al. (2006) observed a higher value for the intrinsic rate of increase $\left(r_{m}=0.28\right)$, suggesting that the pollen of that plant can be used satisfactorily for rearing of $N$. californicus.
The mean generation time ( $\mathrm{T})$ was 17.2 days, the net reproduction rate $\left(R_{0}\right)$ was 18.7 females and the finite rate of increase $(\lambda)$ was 1.2 females/day. The mean generation time and the finite rate of increase were similar to the values found by Canlas et al. (2006) with the predator feeding on T. urticae, there not being large differences when compared with castor bean pollen in this study. The population is estimated to double (TD) every 4.07 days (Table 4). Rahmani et al. (2009) verified that the finite rate of increase $(\lambda)$ was 0.04 when $N$. californicus fed on $T$. tabaci and in the present study with castor bean pollen it was 1.2. It is known that the higher the finite rate of increase, the higher the daily population growth. However, it should be taken into account that the ideal laboratory conditions are considered for the reproduction and development of the predatory mite. In the greenhouse and mainly in the field, it is expected that the predatory mite is subjected to various ecological factors that can alter its reproductive and developmental capacity. 
Table 3. Fertility life table of Neoseiulus californicus in laboratory at $25^{\circ} \mathrm{C}, 70 \pm 10 \% \mathrm{RH}$ and a 14 hour photophase, fed on castor bean plant (Ricinus communis) pollen $(\mathrm{n}=100)$.

\begin{tabular}{|c|c|c|c|c|}
\hline $\mathrm{x}^{*}$ & Mx** & $\mathbf{L x} * * *$ & Mx.Lx & Mx.Lx.x \\
\hline 9.5 & 1.08 & 1 & 1.08 & 10.26 \\
\hline 10.5 & 0.83 & 1 & 0.83 & 8.72 \\
\hline 11.5 & 0.75 & 1 & 0.75 & 8.63 \\
\hline 12.5 & 0.83 & 1 & 0.83 & 10.38 \\
\hline 13.5 & 0.93 & 1 & 0.93 & 12.56 \\
\hline 14.5 & 0.87 & 1 & 0.87 & 12.62 \\
\hline 15.5 & 0.70 & 1 & 0.70 & 10.85 \\
\hline 16.5 & 0.78 & 1 & 0.78 & 12.87 \\
\hline 17.5 & 0.81 & 1 & 0.81 & 14.18 \\
\hline 18.5 & 0.86 & 1 & 0.86 & 15.91 \\
\hline 19.5 & 0.82 & 1 & 0.82 & 15.99 \\
\hline 20.5 & 0.75 & 1 & 0.75 & 15.38 \\
\hline 21.5 & 0.72 & 1 & 0.72 & 15.48 \\
\hline 22.5 & 0.69 & 1 & 0.69 & 15.53 \\
\hline 23.5 & 0.70 & 1 & 0.70 & 16.45 \\
\hline 24.5 & 0.74 & 1 & 0.74 & 18.13 \\
\hline 25.5 & 0.69 & 0.99 & 0.68 & 17.42 \\
\hline 26.5 & $0, .66$ & 0.99 & 0.65 & 17.32 \\
\hline 27.5 & 0.65 & 0.99 & 0.64 & 17.70 \\
\hline 28.5 & 0.58 & 0.99 & 0.57 & 16.36 \\
\hline 28.5 & 0.58 & 0.99 & 0.57 & 16.36 \\
\hline 30.5 & 0.47 & 0.95 & 0.45 & 13.62 \\
\hline 31.5 & 0.46 & 0.90 & 0.41 & 13.04 \\
\hline 32.5 & 0.51 & 0.86 & 0.44 & 14.25 \\
\hline 33.5 & 0.45 & 0.75 & 0.34 & 11.31 \\
\hline 34.5 & 0.45 & 0.70 & 0.32 & 10.87 \\
\hline 35.5 & 0.72 & 0.67 & 0.48 & 17.13 \\
\hline 36.5 & 0.36 & 0.66 & 0.24 & 8.67 \\
\hline 37.5 & 0.00 & 0.62 & 0.00 & 0.00 \\
\hline- & - & - & $\Sigma=\mathrm{Ro}=18.66$ & 387.94 \\
\hline
\end{tabular}

*Age interval in days; **Specific fertility (progeny of females/female); ***Probability of survival (proportion of living females).

Table 4. Population growth parameters of Neoseiulus californicus in the laboratory at $25^{\circ} \mathrm{C}, 70 \pm 10 \% \mathrm{RH}$ and a $14 \mathrm{~h}$ photophase, fed on castor bean plant (Ricinus communis) pollen.

\begin{tabular}{lrccc}
\hline Parameters & In this paper & Bellini (2008) & Canlas et al. (2006) & Vasconcelos (2006) \\
\hline Ro (Female) & 18.70 & 1.050 & 22.920 & 34.40 \\
$\mathrm{r}_{\mathrm{m}}$ (Female/Female/Day) & 0.17 & 0.002 & 0.209 & 0.26 \\
$\lambda$ (Female/Day) & 1.20 & 1.002 & 2.230 & 1.25 \\
$\mathrm{~T}$ (Day) & 17.20 & 20.700 & 17.550 & 16.90 \\
TD (Day) & 4.07 & - & - & - \\
\hline
\end{tabular}

Ro $=$ net reproduction rate; $r_{m=}$ intrinsic rate of increase; $\lambda=$ finite rate of increase; $T=$ mean generation time; $T D=$ estimated time for the population to double.

\section{Conclusion}

Considering the results here obtained it can be concluded that Neoseiulus californicus large scale rearing for subsequent use in biological control of the two spotted spider mite in greenhouse is viable with pollen from the castor bean plant.

\section{Acknowledgements}

To the Fundação de Amparo à Pesquisa do Estado de Minas Gerais - Fapemig, for financial support and scholarships granted and, to the Conselho Nacional de Desenvolvimento Científico e Tecnológico - CNPq for scholarships granted and, to Professor Luis Carlos Dias da Rocha, of the IFSULDEMINAS, campus Inconfidentes, for providing the mite $N$. californicus.

\section{References}

ALATAWI, F., NECHOLS, JR. and MARGOLIES, DC., 2011. Spatial distribution of predators and prey affect biological control of two spotted spider mites by Phytoseiulus persimilis in 
greenhouses. Biological Control, vol. 56, no. 1, p. 36-42. http:// dx.doi.org/10.1016/j.biocontrol.2010.09.006.

BELLINI, MR., 2008. Manejo de Tetranychus urticae Koch (Tetranychidae) em plantas ornamentais. Piracicaba: Escola Superior de Agricultura Luiz de Queiroz, Universidade de São Paulo. 141 p. [Tese de Doutorado em Entomologia].

CANLAS, LJ., MAMANO, H., OCHIAI, M. and TAKEDA, M., 2006. Biology and predation of the strain Japanese of Neoseiulus californicus (McGregor) (Acari: Phytoseiidae). Systematic and Applied Acarology, vol. 11, no. 2, p. 141-157.

CHAPMAN, RB. and MARTIN, NA., 2005. Spider mite resistance management strategy. In MARTIN, NA., BERESFORD, RM. and HARRINGTON, KC. (Eds.). Pesticide Resistance: prevention and management strategies. Hasting: New Zealand Plant Protection Society. Available from: < http://www.nzpps.org/resistance/pdfs/ spidermite.pdf $>$. Access in: December 2010.

FADINI, MAM., VENZON, M., OLIVEIRA, HG. and PALLINI, A., 2006. Manejo integrado das principais pragas do morangueiro. In CARVALHO, SP. (Org.). Morango: cultivo convencional, segurança alimentar, cultivo orgânico. Belo Horizonte: FAEMG, vol. 1, p. 81-95.

FERRERO, M., CALVO, FJ., ATUAHIVA, T., TIXIER, M-S. and KREITER, S., 2011. Biological control of Tetranychus evansi Baker \& Pritchard and Tetranychus urticae Koch by Phytoseiulus longipes Evans in tomato greenhouses in Spain[Acari: Tetranychidae, Phytoseiidae]. Biological Control, vol. 58, no. 1, p. 30-35. http:// dx.doi.org/10.1016/j.biocontrol.2011.03.012.

GOTOH, T., YAMAGUCHI, K. and MORI, K., 2004. Effect of temperature on life history of the predatory mite Amblyseius (Neoseiulus) californicus (Acari: Phytoseiidae). Experimental \& Applied Acarology, vol. 32, no. 1-2, p. 15-30. http://dx.doi. org/10.1023/B:APPA.0000018192.91930.49. PMid:15139269

GRBIĆ, M., VAN LEEUWEN, T., CLARK, RM., ROMBAUTS, S., ROUZÉ, P., GRBIĆ, V., OSBORNE, EJ., DERMAUW, W., NGOC, PC., ORTEGO, F., HERNÁNDEZ-CRESPO, P., DIAZ, I., MARTINEZ, M., NAVAJAS, M., SUCENA, É., MAGALHÃES, S., NAGY, L., PACE, RM., DJURANOVIĆ, S., SMAGGHE, G., IGA, M., CHRISTIAENS, O., VEENSTRA, JA., EWER, J., VILLALOBOS, RM., HUTTER, JL., HUDSON, SD., VELEZ, M., YI, SV., ZENG, J., PIRES-DASILVA, A., ROCH, F., CAZAUX, M., NAVARRO, M., ZHUROV, V., ACEVEDO, G., BJELICA, A., FAWCETT, JA., BONNET, E., MARTENS, C., BAELE, G., WISSLER, L., SANCHEZ-RODRIGUEZ, A., TIRRY, L., BLAIS, C., DEMEESTERE, K., HENZ, SR., GREGORY, TR., MATHIEU, J., VERDON, L., FARINELLI, L., SCHMUTZ, J., LINDQUIST, E., FEYEREISEN, R. and VAN DE PEER, Y., 2011. The genome of Tetranychus urticae reveals herbivorous pest adaptations. Nature, vol. 479, no. 7374, p. 487-492. http:// dx.doi.org/10.1038/nature10640. PMid:22113690

MORAES, GJ. and FLECHTMANN, CHW., 2008. Manual de acarologia: acarologia básica e ácaros de plantas cultivadas no Brasil. Ribeirão Preto: Holos. 308 p.

OPIT, GP., NECHOLS, JR. and MARGOLIES, DC., 2004. Biological control of two spotted spider mites, Tetranychus urticae Koch (Acari: Tetranychidae), using Phytoseiulus persimilis Athias-Henriot (Acari: Phytoseiidae) on ivy geranium: assessment of predator release ratios. Biological Control, vol. 29, no. 3, p. 445-452. http://dx.doi.org/10.1016/j.biocontrol.2003.08.007.
POLETTI, M., KONNO, RH., SATO, ME. and OMOTO, C.,2006. Controle biológico aplicado do ácaro rajado em cultivo protegido: viabilidade no emprego dos ácaros predadores. In PINTO, AS., NAVA, DE., ROSSI, MM. and MALERBO-SOUZA, DT. (Orgs.). Controle biológico de pragas: na prática. Piracicaba: FEALQ. p.193-203.

PREVERIERI, GS., SIMONI, S. and LIGUORI, M., 2006. Suitability of Quercus ilex pollen for rearing four species of phytoseiid mites (Acari: Phytoseiidae). Redia. Frienze, vol. 89, p. 65-71.

REIS, PR. and ALVES, EB., 1997. Criação do ácaro predador Iphiseiodes zuluagai Denmark\&Muma (Acari: Phytoseiidae) em laboratório. Anais da Sociedade Entomológica do Brasil, vol. 26, no. 3, p. 565-568. http://dx.doi.org/10.1590/S030180591997000300021

REIS, PR., SILVA, EA. and ZACARIAS, MS., 2005. Controle biológico de ácaros em cultivos protegidos. Informe Agropecuário, vol. 26 , no. 225 , p. $58-67$

REIS, PR., TEODORO, AV., PEDRO NETO, M. and DA SILVA, EA., 2007. Life history of Amblyseius herbicolus (Chant) (Acari: Phytoseiidae) on coffee plants. Neotropical Entomology, vol. 36, no. 2, p. 282-287. http://dx.doi.org/10.1590/S1519566X2007000200016. PMid:17607463

RAHMANI, H., FATHIPOUR, Y. and KAMALI, K., 2009. Life history and population growth parameters of Neoseiulus californicus (Acari: Phytoseiidae) fed on Thrips tabaci (Thysanoptera: Thripidae) in laboratory conditions. Systematic and Applied Acarology, vol. 14, p. 91-100.

SATO, ME.,SILVA, M., GONÇALVES, LR., SOUZA FILHO, MF. and RAGA, A., 2002a. Toxicidade diferencial de agroquímicos a Neoseiulus californicus (McGregor) (Acari: Phytoseiidae) e Tetranychus urticae Koch (Acari: Tetranychidae) em morangueiro. Neotropical Entomology, vol. 31, no. 3, p. 449-456. http://dx.doi. org/10.1590/S1519-566X2002000300016.

SATO, ME., SILVA, MZ., SOUZA-FILHO, MF. and RAGA, A., 2002b. Manejo de Tetranychus urticae Koch (Acari: Tetranychidae) em morangueiro utilizando ácaros predadores (Phytoseiidae) e propargite. Arquivos do Instituto Biologico, vol. 69, p. 261-264.

SATO, ME., SILVA, MZ., SOUZA FILHO, MF. and RAGA, A., 2006. Monitoramento da resistência de Tetranychus urticae (Koch) (Acari: Tetranychidae) a abamectin e fenpyroximate em diversas culturas no Estado de São Paulo. In Resumos do I Simpósio Brasileiro de Acarologia, 2006. Viçosa. Viçosa: Universidade Federal de Viçosa. p. 169

SATO, ME., SILVA, MZ., CANGANI, KG. and RAGA, A., 2007. Seleções para resistência e suscetibilidade, detecção e monitoramento da resistência de Tetranychus urticae Koch (Acari: Tetranychidae) ao acaricida clorfenapir. Bragantia, vol. 66, no. 1, p. 89-95. http://dx.doi.org/10.1590/S0006-87052007000100011.

SATO, ME., SILVA, MZ., SILVA, RB., SOUZA FILHO, MF. and RAGA, A., 2009. Monitoramento da resistência de Tetranychus urticae Koch (Acari: Tetranychidae) a abamectin e fenpyroxymate em diversas culturas no Estado de São Paulo. Arquivos do Instituto Biologico, vol. 76, no. 2, p. 217-223.

SILVEIRA NETO, S., NAKANO, O., BARBIN, D. and VILANOVA, NA., 1976. Manual de ecologia dos insetos. São Paulo: Agronômica Ceres, $419 \mathrm{p}$. 
TANIGOSHI, LK., HOYT, SG., BROWNE, RW. and LOGAN, JA., 1975. Influence of temperature on population increase of Metaseiulus occidentalis (Acarina: Phytoseiidae). Annals of the Entomological Society of America, vol. 68, no. 6, p. 979-986.

UNIVERSITY OF UTAH, 2011. Big pest, small genome: two spotted spider mite genome decoded. ScienceDaily. Available from: $<$ http://www.sciencedaily.com/releases/2011/11/111123133125. htm>. Access in: January 2012.
VASCONCELOS, GJN., 2006. Eficiência dos ácaros predadores Phytoseiulus fragariae e Neoseiulus californicus (Acari: Phytoseiidae) em Licopersicon esculentum e Solanum americanum. Piracicaba: Escola Superior de Agricultura Luiz de Queiroz, Universidade de São Paulo. 81 p. [Dissertação de Mestrado em Entomologia].

ZHANG, ZQ., 2003. Mites in greenhouse: identification, biology and control. Cambridge: CABI Publishing, 244 p.. http://dx.doi. org/10.1079/9780851995908.0000. 